\title{
The Use of Liquid Organic Fertilizer As Growth Media and Production of Kangkung (Ipomoea reptans Poir) Hydroponics
}

\author{
Dali Andrian', Ahmad Rafiqi Tantawi' ${ }^{1}$ \& Abdul Rahman ${ }^{1}$ \\ ${ }^{1}$ Faculty of Agriculture, University of Medan Area, Indonesia \\ daliumafp@gmail.com
}

\begin{abstract}
This study aims to determine the effect of different concentrations of liquid fertilizer with hydroponic planting media on kale production. The research method used was Randomized Completely Factorial Design with 2 factors: POC cocoa skin and cocoa poc added with cow dung. This study consisted of 16 treatment combinations each repeated 2 times. So there are 32 units of the whole experiment. Parameters observed include: percentage of growth, plant height, number of leaves (leaf), leaf area (), measuring leaf color, wet weight of harvest, wet weighted weighing, root length measurement. Based on the results of research that has been carried out can be concluded as follows: Provision of liquid organic fertilizer from cocoa leather and organic fertilizer liquid cow dung on the growth and production of kale plants showed unequal generative growth. The dosage of liquid organic fertilizer (POC) given by kangkung plantation has no effect on the increase of observed parameters from plant height, leaf number, leaf color, leaf area, and wet weight of the plant. In the excess of nutrient elements.
\end{abstract}

Keywords : liquid organic fertilizer; growth and production medi; kangkung plants; hydroponics

\section{Introduction}

Kangkung (Ipomoea reptans Poir) is an important vegetable plant in Southeast Asia and South Asia. This vegetable is easily cultivated and short-lived. In addition to vegetables, kale containing certain compounds is also useful in the pharmaceutical industry (Djuariah 1997). In Indonesia there are two types of kale, namely land water spinach and water spinach. Land kale grows on dry land and paddy fields, while water spinach grows in water, both balong and river water. Known local cultivars are Lombok water spinach and Sukabumi water spinach, both of which have high quality with bright, attractive and wide green leaf characteristics (typically land spinach) and crispy trunks (Abidin et al. 1990).

Hydroponic Agriculture can be one of the solutions to solve the problem of agricultural land. Hydroponics comes from the word hydro which means water and ponic which means workmanship, so hydroponics can be interpreted as a technique of plant cultivation using planting media other than soil and utilizing water to channel nutrients needed to each plant (Lingga, 1985).

Hydroponics also has several advantages including the cultivation that does not depend on climate, continuous crop yields, and more practical plant care, commodities that are often cultivated with hydroponics are horticultural commodities. Horticulture commodities have a short harvesting age and small morphology so that they are easily cultivated hydroponically. This reason is why hydroponics can be one of the cultivation techniques suitable for water spinach (Lingga, 1985).

Water is an element that cannot be eliminated for the survival of living things including plants. In hydroponic techniques, water is an important factor because the nutrients needed by plants are given through water on plants influenced by several important factors including plant species, plant shape, plant age, conditions around the plant, type of planting 
media, and plot size, although water is an important factor for hydroponic plants, its use must be carried out as efficiently as possible because of the diminishing source of clean water, savings in the use of fertilizers, which can reduce production costs (Lingga, 2007).

Sources of nutrition given to kale with hydroponic planting systems can come from cacao peel waste according to Goenadi et, al (2000) content of $1.81 \% \mathrm{~N}, 26.61 \% \mathrm{C}$-organic, $0.31 \% \mathrm{P} 2 \mathrm{O} 5,6.08 \% \mathrm{~K} 2 \mathrm{O}, 1.22 \% \mathrm{CaO}, 1.37 \% \mathrm{MgO}$, and $44.85 \mathrm{cmol} / \mathrm{kg}$ CEC (kaloit exchange capacity). Research conducted found that nutrient content of compost made from cocoa peel can increase production by $19.48 \%$. With a combination of cow dung that has dried out and dissolved again with water with a nitrogen content of $28.1 \% \mathrm{~N}, 9.1 \% \mathrm{P}$ and $20.0 \% \mathrm{~K}$ in composted cow manure (Setiawan, A.I. 2002). This study aims to determine the effect of giving different concentrations of liquid fertilizer with hydroponic planting media on the production of kale.

\section{Methodology}

The materials used to carry out the research are as follows: Water spinach seeds, composted liquid organic fertilizers (cocoa skin and cow dung), Water, Brown sugar, EM4, and Yeast. The tools needed are as follows: PVC sized gutters (P $390 \mathrm{~cm}$ x L $12 \mathrm{~cm} \mathrm{x} 15 \mathrm{~cm})$, Wood gutters, Binding wire, Foam, Markers, Scissors, Knives, Rollers, Stationery. Solder, iron railings, and cask for composting.

The research method used was Factorial Completely Randomized Design with 2 factors, namely cocoa skin POC and cocoa skin POC added with cow dung. This study consisted of 16 combinations of treatments each repeated twice. So there are 32 whole experimental units. Then analysis of variance was carried out and if it showed a significant difference, it was followed by an average test of Duncan Multiple Range Test (DMRT) at the level of 5\% (Sastrosupadi, 2002). The parameters observed included: percentage of growth, plant height, number of leaves (strands), leaf area (), measuring leaf color, harvest wet weight, selling wet weight weight, measurement of root length.

\subsection{Plant Height (cm)}

\section{Results and Discussion}

Observation data of water spinach plant height carried out in gauze by giving, cocoa skin liquid organic fertilizer to each treatment level A0, A3, A2, and A1 combined with liquid organic fertilizer from cocoa skin and cow manure liquid manure in each treatment B0, B3, B2, and B1. At observations 5, 10 and 15 days after planting can be seen in Table 1, on observing 1 water spinach plant, measurements showed that the treatment of liquid organic fertilizer from cocoa peel and liquid organic fertilizer from cow manure also had no significant effect on other combination treatments.

Table 1. Average water spinach plant height $(\mathrm{cm})$ aged 5-15 HST in treatment Using liquid organic fertilizer as a hydroponic growth medium for water spinach (Ipomoea reptans Poir) 


\begin{tabular}{cccccc}
\hline \multirow{4}{*}{$\mathrm{P}$} & \multicolumn{3}{c}{ Observation } & Total & Average \\
\cline { 2 - 4 } & 1 & 2 & 3 & & \\
\hline A0B0 & 12,25 & 13,48 & 16,40 & 42,12 & 14,04 \\
A0B1 & 12,51 & 15,85 & 20,20 & 48,56 & 16,19 \\
A0B2 & 10,95 & 12,92 & 18,20 & 42,07 & 14,02 \\
A0B3 & 10,78 & 11,85 & 17,26 & 39,89 & 13,30 \\
A1B0 & 12,40 & 13,43 & 16,53 & 42,35 & 14,12 \\
A1B1 & 12,32 & 13,64 & 19,71 & 45,67 & 15,22 \\
A1B2 & 12,49 & 15,27 & 19,15 & 46,91 & 15,64 \\
A1B3 & 14,43 & 17,06 & 24,65 & 56,14 & 18,71 \\
A2B0 & 11,65 & 14,81 & 20,10 & 46,56 & 15,52 \\
A2B1 & 11,62 & 13,15 & 18,03 & 42,79 & 14,26 \\
A2B2 & 11,13 & 15,08 & 22,33 & 48,53 & 16,18 \\
A2B3 & 12,56 & 14,15 & 19,25 & 45,96 & 15,32 \\
A3B0 & 12,95 & 14,04 & 18,10 & 45,09 & 15,03 \\
A3B1 & 12,81 & 14,73 & 19,50 & 47,04 & 15,68 \\
A3B2 & 14,27 & 15,90 & 18,26 & 48,43 & 16,14 \\
A3B3 & 11,95 & 14,50 & 18,15 & 44,60 & 14,87 \\
\hline
\end{tabular}

From Table 1, the average results of observational analysis of water spinach plant height have different heights, from the results of the first and second measurements found in treatment A1B3, in the third observation the highest results $(24.65 \mathrm{~cm})$ in treatment (A1B3), with level of liquid cocoa organic fertilizer without liquid organic fertilizer cow manure (A1) $375 \mathrm{ml}$ combined + liquid organic fertilizer cocoa skin and cow manure (B3) $500 \mathrm{ml}+1525$ $\mathrm{ml}$ liters of liquid organic fertilizer in each treatment, and the lowest yield is in treatment (A0B3), (A0) 950 liters of water combined + liquid organic fertilizer from cacao skin and 500 $\mathrm{ml}(\mathrm{B} 2)+950 \mathrm{ml}$ liters of water from cow manure.

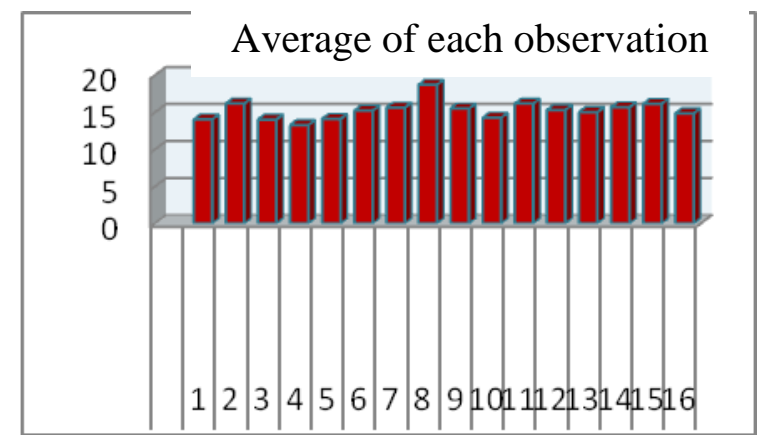

Figure 3. Average Histogram of the Results of High Analysis of Watercress Plants

Observations 1, 2 and 3.

From Figure 3 shows the average of all observations of water spinach plant height, the water spinach growth rate was started highest in A1B3 treatment, the optimal growth rate of 
kale was seen with the dosage used while the second growth rate in treatment A0B2 where more than the specified dose would get optimal results or decrease in yield, the lowest growth rate in treatment $\mathrm{A} 0 \mathrm{~B} 3$ with the use of doses without combinations saw a corresponding growth, from observations 5, 10, 15 days after planting, seen from Table 1 showed the average yield of each first observation was not apparent from each treatment. But treatment of A1B3 (14.43) showed the highest treatment compared to other treatments.

Whereas in the second observation it was not real with other treatments but in the treatment A1B3 (17.06) the highest yield with other treatments and the third observation treatment was also not real but the highest yield was A1B3 (24.65). Based on the results of the average treatment for each of the first, second, and third observations, the highest water spinach plant was found in A1B3 treatment and the smallest was found in the A0B3 treatment. In the observation it was seen that in each test result there was a diversity of high and low values of water spinach from each treatment and observed observations.

From the results of observations made up to 15 days after planting, it can be seen in Table 1, the average yield of plant height observations showed a different average yield of plant height, from treatment A1B3 where the dosage of liquid organic fertilizer made from cocoa pods and impurities organic fertilizer cows showed the highest increase in plant height at each observation, with symptoms of increasing plant height different from the lowest to highest doses, where the use of high doses of cow organic fertilizer from cow dung was very influential for kale plants so that the plants experienced wilt. The highest use of doses of liquid organic fertilizer from cow dung given to each treatment showed a decrease in plant height while the lowest use of liquid organic fertilizer for cow dung showed the same increase. While the use of cocoa skin liquid organic fertilizer has a relatively balanced impact on plant height ranging from the highest to the lowest dose. The provision of liquid organic fertilizer aims to maintain the availability of nutritional plants to remain balanced during the growth process.

\subsection{Number of Kangkung Leaves (Strands)}

Observation data on the number of water spinach leaves from the administration of liquid cocoa organic fertilizer to each treatment level A0, A3, A2, and A1 combined with liquid cocoa organic fertilizer and cow manure liquid fertilizer in each treatment B0, B3, B2, and $\mathrm{B} 1$ are presented in Table 2. From Table 2, in observations 1, 2, 3, observations of leaf numbers showed that the treatment of liquid organic fertilizer from cocoa skin and cow manure liquid organic fertilizer also had no significant effect with other combination dosage treatments.

On measurement of the third observation shows the highest yield of 6.55 strands in the treatment (A2B2), with the level of liquid organic fertilizer of cacao peel without liquid manure (A2) liquid organic fertilizer $375 \mathrm{ml}$ combined with liquid cocoa organic fertilizer and organic fertilizer liquid cow dung (B2) $375 \mathrm{ml}+1650 \mathrm{ml}$ liters of water.

Table 2. Average number of leaves of water spinach $(\mathrm{cm})$ aged 5-10-15 HST in the treatment of using liquid organic fertilizer as a hydroponic growth medium for water spinach (Ipomoea reptans Poir) plants. 


\begin{tabular}{cccccl}
\hline \multirow{2}{*}{$\mathrm{P}$} & \multicolumn{3}{c}{ Observation } & \multirow{2}{*}{ Total } & \multirow{2}{*}{ Average } \\
\cline { 2 - 4 } & 1 & 2 & 3 & & \\
\hline A0B0 & 2,80 & 4,35 & 5,60 & 12,75 & 4,25 \\
A0B1 & 2,50 & 4,60 & 6,25 & 13,35 & 4,45 \\
A0B2 & 2,95 & 5,15 & 6,45 & 14,55 & 4,85 \\
A0B3 & 2,50 & 4,45 & 5,75 & 12,70 & 4,23 \\
A1B0 & 3,05 & 4,85 & 5,95 & 13,85 & 4,62 \\
A1B1 & 2,65 & 4,05 & 5,25 & 11,95 & 3,98 \\
A1B2 & 3,10 & 4,95 & 5,90 & 13,95 & 4,65 \\
A1B3 & 2,90 & 4,95 & 6,30 & 14,15 & 4,72 \\
A2B0 & 2,75 & 4,65 & 6,25 & 13,65 & 4,55 \\
A2B1 & 2,50 & 4,40 & 5,60 & 12,50 & 4,17 \\
A2B2 & 2,90 & 4,95 & 6,55 & 14,40 & 4,80 \\
A2B3 & 2,65 & 4,25 & 5,70 & 12,60 & 4,20 \\
A3B0 & 2,65 & 4,80 & 5,90 & 13,35 & 4,45 \\
A3B1 & 2,95 & 4,50 & 5,80 & 13,25 & 4,42 \\
A3B2 & 3,15 & 4,40 & 5,70 & 13,25 & 4,42 \\
A3B3 & 3,05 & 4,55 & 5,85 & 13,45 & 4,48 \\
\hline
\end{tabular}

Table 2 shows that the treatment of cow manure liquid organic cocoa peel combination at a fertilizer dose of $375 \mathrm{ml} \mathrm{A}+375 \mathrm{ml} \mathrm{B}+1650 \mathrm{ml}$ liters of water (A2B2), has increased growth in the number of leaves by 6, 55 strands of control fertilizer dose, and experienced the growth of the number of leaves of most plants compared to other doses, did not significantly affect the number of leaf spinach observed.

Based on the treatment average in Table 2 on the first, second, and third observation averages indicated that the highest number of leaf spinach plants was obtained in the treatment (A0B2) with a level of $2025 \mathrm{ml}$ liters of water + (B2) $375 \mathrm{ml}$, and the smallest is in the treatment (A1B1) with the level of liquid organic fertilizer without liquid organic fertilizer cow manure (A1) $375 \mathrm{ml}+$ with liquid organic fertilizer cocoa skin and liquid organic fertilizer cow manure (B1) $375 \mathrm{ml}+1650 \mathrm{ml}$ liters of water. In observations it was seen that in each replication there was a diversity of values of high and low water spinach plants from each treatment observed starting from observations 5, 10 and 15 days after planting.

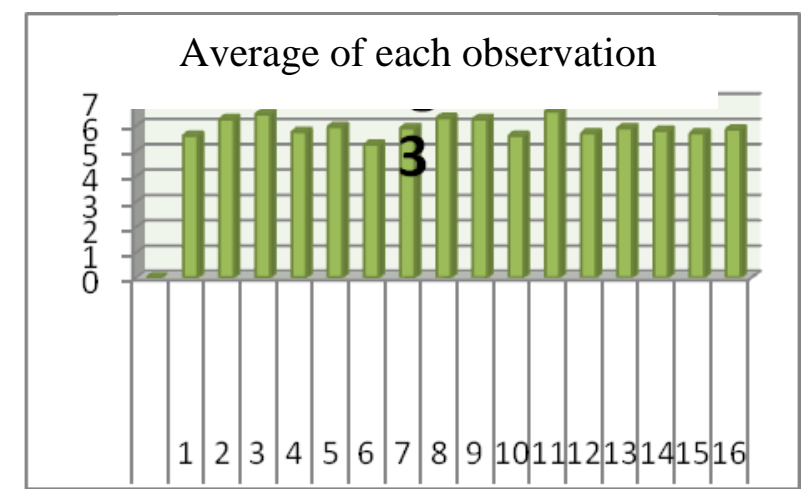

Figure 4. Average histogram of the results of analysis of the number of leaves of spinach plant observation 3 .

From Figure 4 can be seen the increase in the number of kale leaves observed in the third observation that is 15 days after planting, the highest decrease in the number of leaves with the treatment of A3B3 and A1B1 with the use of organic fertilizers equal to the growth of the number of kale leaves in $\mathrm{A} 2 \mathrm{~B} 2$ get optimal results compared to other treatments, in 
Table 2 the first observation shows the unreal results of each treatment caused by plants experiencing excess nutrients given, so poisoning. On treatment A3B2 (3.15) showed the highest results compared to other treatments. Whereas the second observation was not real with different results in treatment A0B2 (5.15) which was the highest result with other treatments and the third observation treatment was also not real but the highest yield was A2B2 (6.55).

\subsection{Width of Kangkung Leaves (cm2)}

From the observation data, the area of kangkung leaves by measuring the area of kale leaves involves a drawing tool, namely millimeter paper. With the treatment of giving liquid cocoa organic fertilizer to each treatment level A0, A3, A2, and A1. Combined with liquid cocoa organic fertilizer and cow manure liquid fertilizer in each treatment B0, B3, B2, and B1. At observations 5, 10 and 15 HST can be seen in Table 3, in observing 1 kale plant, measurement showed that the treatment of liquid organic fertilizer from cocoa skin and cow manure liquid organic fertilizer also had no significant effect with other combination treatments.

From the measurement results of the third observation showed the highest yield of $34.95 \mathrm{~cm}^{2}$ in treatment (A1B1), with the level of cocoa skin liquid organic fertilizer without cow manure (A1) $375 \mathrm{ml}$ with liquid cocoa organic fertilizer and cow manure liquid manure ( B1) $375 \mathrm{ml}+1650 \mathrm{ml}$ liters of water. To be clearer, below is a diagram of the area of kangkung leaves on observations from 5-10-15 days after planting.

Table 3. Average Measurement of Leaf Area (cm2) Water spinach Plants Age 5, 10, 15 days after planting.

\begin{tabular}{llllll}
\hline \multirow{2}{*}{ P } & \multicolumn{2}{l}{ Observation } & Total & Average \\
\cline { 2 - 4 } & 1 & 2 & 3 & & \\
\hline A0B0 & 24,85 & 29,20 & 33,10 & 87,15 & 29,05 \\
A0B1 & 24,70 & 29,60 & 32,85 & 87,15 & 29,05 \\
A0B2 & 24,70 & 28,30 & 33,70 & 86,70 & 28,90 \\
A0B3 & 25,20 & 29,85 & 34,60 & 89,65 & 29,88 \\
A1B0 & 23,25 & 27,65 & 32,90 & 83,80 & 27,93 \\
A1B1 & 25,75 & 30,50 & 34,95 & 91,20 & 30,40 \\
A1B2 & 23,80 & 27,60 & 33,85 & 85,25 & 28,42 \\
A1B3 & 24,10 & 28,00 & 35,55 & 87,65 & 29,22 \\
A2B0 & 22,05 & 27,45 & 31,90 & 81,40 & 27,13 \\
A2B1 & 24,35 & 29,35 & 33,90 & 87,60 & 29,20 \\
A2B2 & 23,85 & 28,40 & 32,95 & 85,20 & 28,40 \\
A2B3 & 23,85 & 28,60 & 33,05 & 85,50 & 28,50 \\
A3B0 & 24,55 & 31,15 & 34,75 & 90,45 & 30,15 \\
A3B1 & 24,00 & 29,00 & 33,80 & 86,80 & 28,93 \\
A3B2 & 22,25 & 27,30 & 32,30 & 81,85 & 27,28 \\
A3B3 & 22,30 & 28,00 & 32,50 & 82,80 & 27,60 \\
\hline & & & & & \\
\hline
\end{tabular}

Results The administration of liquid organic fertilizer A1B1 showed an increase in the highest leaf area observed at 15 days after planting compared to observations 10 days after planting on $\mathrm{A} 3 \mathrm{~B} 0$, and 5 days after planting A1B1 showed a not significant difference from all treatments. 


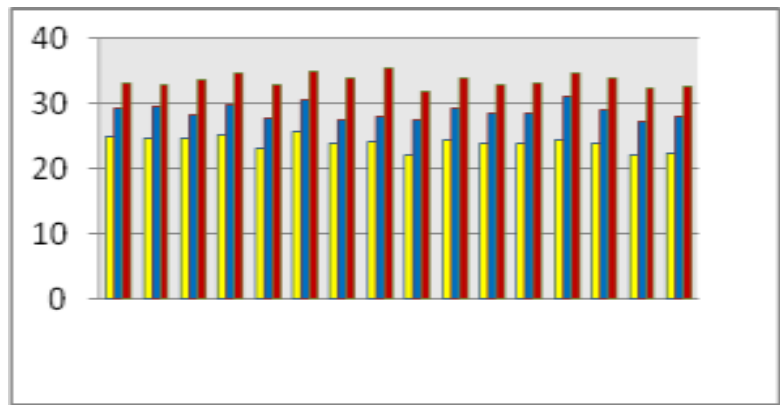

Figure 5. Average Results of Area of Kangkung Leaves in Observations 1, 2 and 3.

From Figure 5 shows the increase in kale leaf area from each observation, in Table 5 the results of the first observation are not real from each treatment seen from each treatment has a uniform leaf area different from each other treatment. At the first observation the treatment of A1B1 $\left(25.75 \mathrm{~cm}^{2}\right)$ showed the highest results compared to other treatments. Whereas the second observation was not real with other treatments but at the treatment of A3B0 $\left(31.15 \mathrm{~cm}^{2}\right)$ was the highest result with other treatments and the third observation treatment was also not real but the highest yield was A3B0 $\left(34.95 \mathrm{~cm}^{2}\right)$. Based on Table 3, the average treatment for each of the first, second, and third observations showed that the highest leaf area of water spinach was found in treatment A1B1 and the smallest was found in treatment $\mathrm{A} 2 \mathrm{~B} 0$. In the observation it was seen that in each test result there was a diversity of the value of kale leaf area which was different from each treatment.

\subsection{Weight of Kangkung}

Observation data of water spinach plant wet weight parameters from several combinations at the age of 15 days (harvest) after planting, with the control treatment and administration of liquid organic fertilizer of cacao skin added with cow dung showed differences in harvest weight of repeat test I and replication II. The wet weight of water spinach can be seen in Figure 6 .

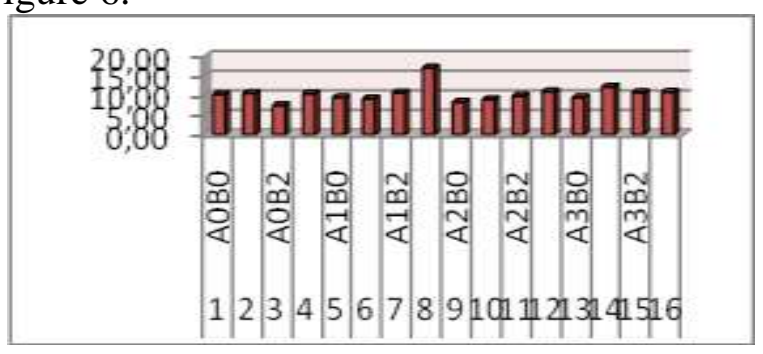

Figure 6. Average Histogram of Kangkung Harvest Results.

The overall yield of measurements of wet water spinach and from the results of the average repeats 1 and 2, on the histogram produced the highest water spinach plant weight in treatment A1B3. The wet weight of test 1 weighing 1100 grams and on the second test produced a wet weight of 600 grams of water spinach. It was seen that at each replication produced a variety of wet weight of water spinach plants which were different where the treatment of liquid organic fertilizer, cocoa peel, and added cow manure and controls 
received different values of different yields and the increase was more dominated by combining mixed cocoa pods. by cow manure.

Table 4. Average the yield of kangkung in each treatment.

\begin{tabular}{ccccc} 
P & \multicolumn{2}{c}{ Repitition } & Total & Average \\
\cline { 2 - 3 } & 1 & 2 & & \\
\hline A0B0 & 5,24 & 15,38 & 20,62 & 10,31 \\
A0B1 & 5,50 & 15,68 & 21,18 & 10,59 \\
A0B2 & 4,80 & 10,30 & 15,10 & 7,55 \\
A0B3 & 10,00 & 11,00 & 21,00 & 10,50 \\
A1B0 & 4,40 & 14,65 & 19,05 & 9,53 \\
A1B1 & 5,20 & 13,27 & 18,47 & 9,24 \\
A1B2 & 9,00 & 12,47 & 21,47 & 10,74 \\
A1B3 & 18,00 & 16,09 & 34,09 & 17,05 \\
A2B0 & 3,70 & 13,03 & 16,73 & 8,37 \\
A2B1 & 5,40 & 12,60 & 18,00 & 9,00 \\
A2B2 & 7,00 & 12,75 & 19,75 & 9,88 \\
A2B3 & 7,90 & 14,10 & 22,00 & 11,00 \\
A3B0 & 4,10 & 14,99 & 19,09 & 9,55 \\
A3B1 & 10,00 & 14,45 & 24,45 & 12,23 \\
A3B2 & 4,70 & 16,91 & 21,61 & 10,81 \\
A3B3 & 8,00 & 13,80 & 21,80 & 10,90 \\
\hline
\end{tabular}

Based on the results of observations on the fresh weight of plants showed that there were significant differences between the treatment of doses of liquid cocoa organic fertilizer and doses of liquid organic fertilizer of cow manure at the age of 15 days after planting. The effect of giving doses of cocoa skin liquid organic fertilizer and doses of liquid organic fertilizer cow dung on the fresh weight of water spinach plants is presented in Table 4.

\subsection{Leaf Color of Kangkung}

Observation data of leaf color of water spinach in measurement 1, control plants and combination of liquid organic fertilizer plus cocoa peel added with cow dung. The average leaf color of water spinach is seen by using a leaf color chart (BWD). Shows an average of 45 BWD. Measurement 2, control plants and combination of liquid organic fertilizer plus cocoa skin added with cow dung. The average leaf color of water spinach is seen by using a leaf color chart (BWD). Shows an average of 4-5 BWD, while measurement 3, plants with control treatment and a combination of liquid organic fertilizer plus cocoa skin added with cow dung. The average leaf color of water spinach plants was seen using a leaf color chart (BWD), showing an average of 5-3 BWD.

\subsection{Wet Weight Selling of Kangkung}

Observation data of wet weight sell water spinach plants from several combinations at the age of 15 days (harvest) after planting with the control and administration of liquid fertilizer and cocoa skin plus cow dung. Wet weight for selling kale plants after cleaning from dirt and wilted leaves, which is obtained by the total treatment safety for selling wet weights weighing 2500 grams. 


\subsection{Root Length of Kangkung}

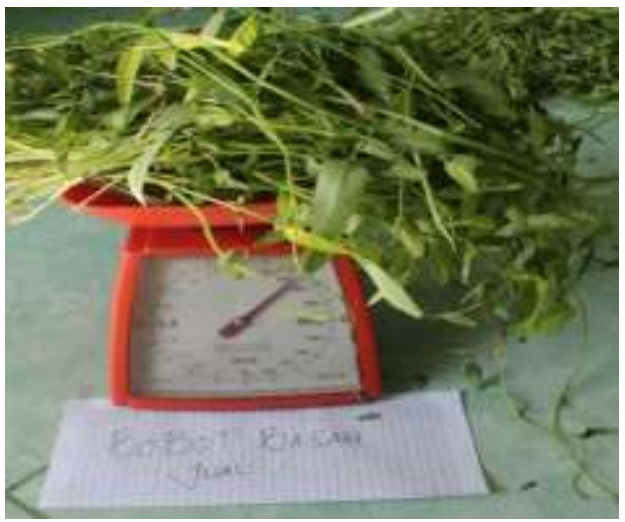

Figure 7. Selling Weight

The observation of root length parameters carried out 15 days after planting, showed differences in the length and height of the roots of water spinach planted in hydroponic direction which showed unreal results from each treatment with the use of liquid organic fertilizers derived from sewage and plants, namely cow dung and cocoa pods composted into organic fertilizer.

From Table 5 observations of root lengths show differences in root length from each treatment not real from each treatment. But the treatment of A1B0, (A1) $375 \mathrm{ml}$ of cocoa skin liquid organic fertilizer without cow manure liquid organic fertilizer combined + control addition (B0) 2025 liters of water, and A3B0, (A3) $500 \mathrm{ml}$ of cocoa skin liquid organic fertilizer without impurities liquid organic fertilizer cows in combination with the addition of control (B0) 2025 liters of water, and A3B1, (A3) $500 \mathrm{ml} \mathrm{ml}$ of liquid organic fertilizer cocoa skin without cow manure + (B1) 375 with liquid cocoa organic fertilizer and cow manure + liquid organic fertilizer 1525 liters of water, showed the highest treatment compared to other treatments, namely $4.15 \mathrm{~cm}$ from replications 1 and 2.

Table 5. Average Measurement of Root Length $(\mathrm{cm} 2)$ Water spinach Plants Age 15 HST treatment time interval in treatment.

\begin{tabular}{lllll}
\hline \multirow{2}{*}{ P } & \multicolumn{2}{l}{ Repititon } & Total & \multirow{2}{*}{ Average } \\
\cline { 2 - 3 } & I & II & & \\
\hline A0B0 & 5,24 & 2,7 & 7,94 & 3,97 \\
A0B1 & 3,3 & 4,1 & 7,40 & 3,70 \\
A0B2 & 3,5 & 4,5 & 8,00 & 4,00 \\
A0B3 & 4,9 & 2,5 & 7,48 & 3,74 \\
A1B0 & 4,4 & 3,9 & 8,30 & 4,15 \\
A1B1 & 5,2 & 2,6 & 7,80 & 3,90 \\
A1B2 & 3,6 & 2,9 & 6,50 & 3,25 \\
A1B3 & 3,6 & 3,5 & 7,10 & 3,55 \\
A2B0 & 3,7 & 3,3 & 7,00 & 3,50 \\
A2B1 & 5,4 & 2,1 & 7,50 & 3,75 \\
A2B2 & 3,5 & 3,4 & 6,90 & 3,45 \\
A2B3 & 4 & 3,3 & 7,30 & 3,65 \\
A3B0 & 4,1 & 4,2 & 8,30 & 4,15 \\
A3B1 & 4 & 4,3 & 8,30 & 4,15 \\
A3B2 & 4,7 & 3,3 & 8,00 & 4,00 \\
A3B3 & 3,6 & 2,3 & 5,90 & 2,95 \\
\hline
\end{tabular}


Each treatment has a varied root length because the use of kangkung plant growth media greatly influences the growth of kale plant roots.

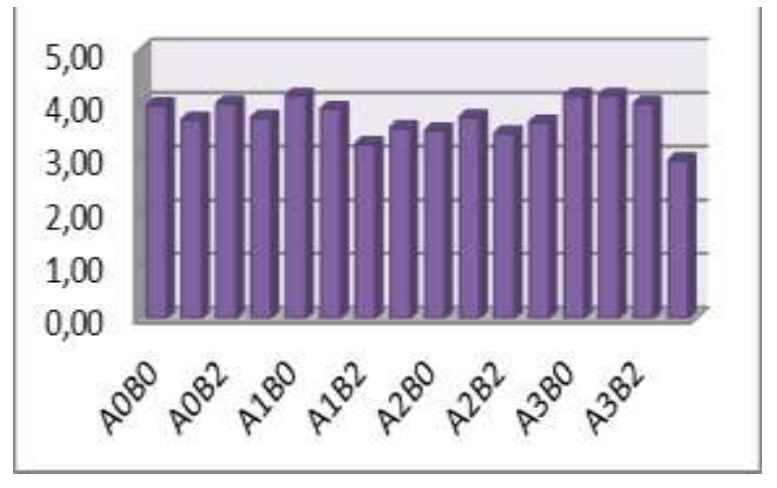

Figure 8. Average Histogram of Root Length of Watercress Plants in Observation 3.

While the smallest treatment was in the treatment of A3B3, (A3) $500 \mathrm{ml}$ of liquid cocoa organic fertilizer without cow manure liquid organic fertilizer, and combined $+(\mathrm{B} 3)$ $500 \mathrm{ml}$ of liquid organic fertilizer cocoa skin and cow manure +1400 liters of liquid organic fertilizer with yield $2.95 \mathrm{~cm}$. In hydropic farming systems root length sampling is influenced by water spinach plant growth media that do not support root sampling for measurement.

\section{IV.Conclusion}

Based on the results of the research that has been carried out, it can be concluded as follows: Provision of liquid organic fertilizer from cocoa peel and cow manure liquid organic fertilizer on the growth and production of water spinach plants shows unequal generative growth. The dosage of liquid organic fertilizer (POC) given in kangkung plants did not affect the increase of parameters observed from plant height, leaf number, leaf color, leaf area, and plant wet weight. Due to excess nutrient elements.

\section{References}

Abidin, Suwarna, Veggel.1990. Pengaruh Cara Penanaman, Jumlah Bibit dan Aplikasi Pemberian Pupuk Nitrogen Terhadap Pertumbuhan dan Hasil Kangkung Darat (Ipomoea reptans Poirs) Pada Tanah Latosol Subang. Bull.

Ajwa H.A. and Tabatabai, MA. 1994. Decompotition of Different Organic Materials in Soils, Biol. Fertil Soils.

Atus'sadiyah, Mir. 2004. Pertumbuhan dan Hasil Tanaman Buncis (Phaseolus vulgarisL) Tipe Tegak Pada Berbagai Variasi Kepadatan Tanaman dan Waktu Pemangkasan Pucuk. Skripsi. Fakultas Pertanian Universitas Brawijaya.

Bambang dan Haryadi 2008 http://www.Gunungwalat.net.id/content/pengukuran-indeksluas-daun-ild-untuk-menduga-evapotrnaspirasi-dengan metode-penma-monteteit

http://muherda.blogspot.com/2011/12/indeks-luas-daunild-leaf-area-indeks.html (accessed again 7-9-2014).

Djuariah, D. (1997). Evaluasi plasma nutfah kangkung di dataran medium.

Darmono. dkk 1999. Tata laksana Usaha Sapi dan pertanian kakao. Kanisius, Yogyakarta. 
Dwidjoseputro (1986), Dwijoseputro,D. 1998. Pengantar Fisiologi Tumbuhan. Gramedia, Jakarta.

Fitter, A.H. and Hay, R.K.M. 1992. Fisiologi Lingkungan Tanaman, University Gadjah Mada Yogyakarta.

Fitter and Hay, (1992). Kotoran Ternak Antara Polusi Lingkungan dan SumberEnergi Alternatif. http//tabliodjubi.wordpress.com/2008/05/07

Goenadi. (2004). Peran Perkebunan dalam PerekonomianI Indoesia, accessed and http://www.ipard.com/art_perkebun/des14-04_wrs-I.asp

Gardner, et. al. (1991), Gardner, Pearce dan Mitchell. 1991. Fisiologi Tumbuhan Budidaya Universitas Indonesia. Jakarta

Ridge I, 1991. Plant Physiology : Form and Function, Hodder \& Stoughton : The Open University

Isro'I, 2008 agricultural university, Bogor. Indrakusuma (2000), Diktat Kuliah Dasar-dasar Fisiologi Tumbuhan Fak. Pertanian Unibraw.

Lingga, P. 1985. Petunjuk Penggunaan Pupuk Cetakan ke-10. Penebar Swadaya. Jakarta. Mackentum, KM. 1969. The Practice of Water Pollution Biology. United State Departemen of The Interior. Federal Water Pollution Control Administration. Devision of The Technikal Support.

Lingga, P. 1999. Hidroponik Bercocok Tanam Tanpa Tanah Cet 17. Penebar Swadaya. Jakarta.

Lakitan B, 1996. Pengaruh Penggunaan Pemberian Pupuk Bokashi Kotoran Sapi Terhadap Pertumbuhan dan Produksi Tanaman Jagung. Jurnal Agribisnis. Juni1996.

Lingga, P. 2007. Hidroponik Bercocok Tanam Tanpa Tanah. Penebar Swadaya. Jakarta.

Lestari, T. 2009. Dampak Konversi Lahan Pertanian Bagi Taraf Hidup Petani. Thesis. Bogor Institut Pertanian Bogor.

Muchtadi, D dan B. Anjarsari. 1995. Penanganan Pascapanen dalam Meningkatkan Nilai Tambah Komoditas Sayuran. Prosiding Seminar Ilmiah Nasional Komoditas Sayuran. Lembang.

Mulyani and Sutedja (1988), Mulyani and Sukaryo. (1989). Tumbuhan dan Organ-organ pertumbuhannya. Jakarta .

Rahmawati Asyad Badan Standarisasi Nasional (BSN). 2004. Spesifikasi Kompos dari Sampah Organik Domestik.

Resh, H. M. 2004. Hydroponic Food Production: A Definitive Guidebook Of Soilless FoodGrowing Methods 6th ed. Newconcept Press. New Jersey.

Rao (1994) dan Purwowidodo (2007) Limbah Ternak Sebagai Sumber Energi Alternatif, Bahan Pakandan Pupuk.

Rukmana R. Bertanam kangkung. Yogyakarta: Kanisius; 1994.

Rosmarkam dan Yowono, (2002) Pertanian Terpadu Suatu Strategi Untuk Mewujudkan Pertanian Berkelanjutan. Online. http://www.tomuato.net.

Sutiyoso, Y., 2004. Hidroponik ala Yos. Penebar Swadaya. Jakarta.

Shitarti dan Takiyah. Klasifikasi botani tanaman kangkung berdasarkan kelas taksonominya.

Soerdarsono (1997). Penanganan Pasca Panen Pangan sebagai Landasan Perkembangan Pertanian Menuju Industrialisasi. 
Opeke. 1984. Analisis Pertumbuhan Tanaman. Gadjah Mada University Press. Yogyakarta Sumber Pertanian http://balitsa.litbang.deptan.go.id/ind/index.php/berita-terbaru/220manfaat-mengkonsumsi-sayur-kangkung-untuk-kesehatan.html.

Setyorini (2005) Setyorini, Diah. 2005. Pupuk Organik Tingkatkan Produksi Pertanian. Warta Penelitian dan Pengem-bangan Pertanian. Balai Penelitian Tanah, Bogor.

Sudarmodjo. 2008. Hidroponik. Parung Farm. Bogor.

Setiawan, A.I. 2002. Memanfaatkan Kotoran Ternak. Cetakan ke tiga Penebar Swadaya. Jakarta Suyitno dan Sudarson (2004), Pengantar Geografi Tumbuhan. : Gadjah Mada University Press Salisbury F.B and Ross, C.W. 1995. Plant Physiology. 1985. Wardworth Publ. Comp. Belmont. Spillane (1995) Pengaruh Limbah Lumpur Industri yang Mengan-dung Logam Berat terhadap Tanaman Kangkung Darat lipomea reptans, Fakultas Pertanian, IPB Bogor.

Suseno 1974, Syafri \& A. Yusri. 2010. Teknologi Pemupukan. Balai Pengkajian Teknologi Pertanian Jambi, metabolisme dalam tanaman.

Tjitrosoepomo, G. 1989. Taksonomi Tumbuhan (Spermatophyta). Yogyakarta: Gadjah Mada University

Utama,I.M.S. 2005. Pascapanen Produk Segar Hortikultura. (http://www.google.co.id) [25Nopember 2009].

Yawono, W. N. 2002. Ilmu Kesuburan Tanah. Penerbit Kanisius. Jogjakarta 